\title{
Site, Competition, and Plant Stock Influence Transplant Success of Wyoming Big Sagebrush
}

\author{
J. Kent McAdoo, ${ }^{1}$ Chad S. Boyd, ${ }^{2}$ and Roger L. Sheley ${ }^{2}$ \\ Authors are ${ }^{1}$ Associate Professor/Natural Resources Specialist, University of Nevada Cooperative Extension, Elko, NV 89801, USA; and ${ }^{2}$ Research \\ Scientist, USDA-ARS Eastern Oregon Agricultural Research Center (EOARC), Burns, OR 97720, USA.
}

\begin{abstract}
Within the sagebrush steppe ecosystem, sagebrush plants influence a number of ecosystem properties, including nutrient distribution, plant species diversity, soil moisture, and temperature, and provide habitat for a wide variety of wildlife species. Recent increases in frequency and size of wildfires and associated annual grass expansion within the Wyoming big sagebrush alliance have increased the need for effective sagebrush restoration tools and protocols. Our objectives were to quantify the success of Wyoming big sagebrush transplants relative to transplant stock (nursery seedlings vs. wildlings) across different ecological sites and vegetation types and to test the hypothesis that reduction of herbaceous vegetation would increase survival of transplanted sagebrush. We used a randomized block (reps=5) design at each of three sites-1) cheatgrass dominated, 2) native plant dominated, and 3) crested wheatgrass dominated-near Elko, Nevada. Treatments included plant stock (nursery stock or locally harvested wildlings) and herbicide (glyphosate) to reduce competition from herbaceous vegetation. Transplants were planted in the spring of 2009 and 2010 and monitored for survival. Data were analyzed for site and treatment effects using mixed-model ANOVA. Surviving plant density at and $2 \mathrm{yr}$ postplanting was generally highest (up to 3-fold) on the native site $(P<0.05)$. Density of surviving transplants was almost 3 -fold higher for nursery stock on most sites for the 2009 planting, but differences in survival by planting stock were minimal for the 2010 planting. Glyphosate application increased surviving plant density up to $300 \%$ (depending on site) for both years of planting. High labor and plant material investments (relative to traditional drilling or broadcasting) may limit the size of projects for which sagebrush transplants are practical, but these costs may be partially offset by high success relative to traditional methods. Our data indicate that sagebrush transplants can be effective for establishing sagebrush on depleted sites.
\end{abstract}

Key Words: competition, crested wheatgrass, island seeding, restoration, sagebrush seedlings, survival, wildlings

\section{INTRODUCTION}

The sagebrush steppe ecosystem is the largest remaining native biome in North America, about 30-50 million ha in total (Comer et al. 2002). Within this area, sagebrush functions in a variety of ecological roles and strongly influences ecosystem pattern and process (West 1983). Sagebrush promotes spatial heterogeneity of nutrient distribution, creating areas of high nutrient concentration that result in unique microsites for understory plant species (i.e., nutrient islands; Jackson and Caldwell 1993a, 1993b; Boyd and Davies 2012a). The microenvironments under sagebrush are also associated with enhanced heterogeneity of other abiotic factors, including soil temperature (Davies et al. 2009) and moisture (Davies et al. 2007) regimes. These varying understory environments have been shown to provide increased establishment of plants from

EOARC is jointly operated by the USDA-ARS and the Oregon State University Agricultural Experiment Station. USDA is an equal opportunity provider and employer.

This paper was funded in part by the USDA-ARS Area-Wide Ecologically Based Invasive Plant Management Program.

Proprietary or trade names are for information only and do not convey endorsement of one product over another.

Correspondence: Chad Boyd, USDA-ARS EOARC, 67826-A Highway 205, Burns, OR 97720, USA. Email: chad.boyd@oregonstate.edu

Manuscript received 19 September 2012; manuscript accepted 29 January 2013.

(c) 2013 The Society for Range Management seed (e.g., perennial grasses) following disturbances such as fire (Boyd and Davies 2010, 2012a). Improved establishment of associated species is important for low to mid-elevation Wyoming big sagebrush (Artemisia tridentata spp. wyomingensis [Beetle \& A. Young] S.L. Welsh) plant communities. In these areas, the need for postfire restoration has escalated in recent years because of increased fire frequency associated with invasion and expansion of nonnative annual grass species (Chambers 2000; Brooks et al. 2004; Davies et al. 2011). Sagebrush is also a critical habitat component for a number of sagebrush-associated wildlife species (Crawford et al. 2004; Shipley et al. 2006; Aldridge et al. 2008; Davies et al. 2011). One of those species, greater sage-grouse (Centrocercus urophasianus), is currently under consideration for listing under provisions of the US Endangered Species Act, a listing that could affect land management activities on millions of acres of rangeland in 11 western US states.

Sagebrush recruitment from existing seed banks is unreliable and apparently episodic under natural conditions (Perryman et al. 2001). Successfully planting sagebrush from seed is similarly challenging because of low and erratic precipitation on drier sites, difficulty in obtaining adequate seed supplies of required subspecies from adapted sites when needed, limited shelf life of seeds, and inadequate cold storage space (Shaw et al. 2005). Unfortunately, restoration of Wyoming big sagebrush on areas where it is critical but absent has also been limited by inadequate restoration techniques and technologies. Typically, sagebrush seed is broadcast aerially or from ground-based 
machinery. By some estimates, failure rates of these methods can exceed $70 \%$ (Lysne and Pellant 2004), making their management efficacy questionable at best when used at low to mid-elevations. Protocols for transplanting existing nearby sagebrush plants have been developed (McArthur and Stevens 2004) but have not been evaluated in the peer-reviewed literature. While limited in spatial extent, such plantings, if successful, could provide a mechanism for establishing sagebrush islands to introduce a sagebrush seed source for longterm sagebrush expansion. In turn, shrub islands can potentially accelerate vegetation recovery of disturbed areas, serving to enhance the local biodiversity of plants and animals (Longland and Bateman 2002).

Regardless of method, difficulties in establishing sagebrush may be amplified by reduced performance of sagebrush plants due to competitive interactions with co-occurring vegetation at restoration sites. Boyd and Svejcar (2011) reported that the presence of native perennial bunchgrasses can substantially delay recovery of sagebrush from seed following disturbance. The nonnative perennial bunchgrass crested wheatgrass has specifically been found to negatively influence establishment of Wyoming big sagebrush (Gunnell et al. 2010). Other authors have prescribed reduction of perennial grasses using targeted grazing by cattle and sheep (Austin et al. 1994; Austin and Urness 1995; Ganskopp et al. 2004) in an effort to increase production of established sagebrush and other shrubs.

The objectives for the present study were to quantify the success of sagebrush transplants in Wyoming big sagebrush plant communities relative to transplant stock (nursery seedlings vs. wildlings) across different ecological sites and vegetation communities and to test the hypothesis that reduction of herbaceous vegetation would increase survival and production of transplanted sagebrush.

\section{METHODS}

\section{Experimental Design and Site Descriptions}

This study employed a randomized block design at each of three sites. Sites were selected according to dominant vegetation as "native," "cheatgrass," or "crested wheatgrass" and were located in the Owyhee High Plateau Major Land Resource Area (MLRA\#25). The native site (1750 m, Loamy 10-12PZ) was located $6 \mathrm{~km}$ north of Elko, Nevada (lat $41^{\circ} 07^{\prime} 30^{\prime \prime} \mathrm{N}$, long $\left.116^{\circ} 52^{\prime} 30^{\prime \prime} \mathrm{W}\right)$, and soils were a gravelly loam surface texture underlain by sandy clay. This area burned in 2003, and dominant species included cheatgrass (Bromus tectorum L.) and the bunchgrasses squirreltail (Elymus elymoides [Raf.] Swezey) and bluebunch wheatgrass (Pseudoroegneria spicata [Pursh] A. Löve). The cheatgrass site (1580 m, Loamy $8-10 \mathrm{PZ}$ ) was $8 \mathrm{~km}$ east of Elko, and soils at this site were fine sandy loam on the surface, underlain by loam. This site burned in 1987 and had low plant diversity. The crested wheatgrass (Agropyron cristatum L.) site $(1615 \mathrm{~m}$, Loamy 810PZ) was located $24 \mathrm{~km}$ south of Elko. This site was seeded with crested wheatgrass during the 1970s and had low plant diversity, and surface soil texture was sandy loam underlain by loam. Cheatgrass was the only annual grass encountered in this study, with none recorded at the crested wheatgrass site.
We established five blocks at each site. Within each block, eight $10-\mathrm{m}^{2}$ circular plots were established; plots within a block were installed at $7.5-\mathrm{m}$ intervals along a $60-\mathrm{m}$ transect. Blocks were arranged within site to be representative of variation in site characteristics, and total site area was approximately $50 \times 180 \mathrm{~m}$. Plots were randomly assigned to planting in 2009 or 2010 and to one of four Wyoming big sagebrush planting treatments, including nursery stock, nursery stock with posttreatment glyphosate application, wildlings (McArthur and Stevens 2004), or wildlings with posttreatment glyphosate application. Wildlings were defined as naturally occurring juvenile plants $<20 \mathrm{~cm}$ in height that were harvested immediately prior to use in the study. Annual precipitation at the sites was approximately $24 \mathrm{~cm}$, with most precipitation falling as snow during the winter months.

\section{Plant Materials and Planting Technique}

Sagebrush nursery stock consisted of individual seedlings planted in $112-\mathrm{mL}$ plastic containers that were grown in a greenhouse under natural lighting conditions at $24^{\circ} \mathrm{C}$, with gradual cooling down to $7.2^{\circ} \mathrm{C}$ used to harden off the stock prior to planting. Nursery seedlings were $6-7$ mo old at time of planting. The age of wildling transplants was unknown, but they were of similar size to nursery stock. Wildlings were harvested from roadsides in the vicinity of study sites using a Weed Wrench (Weed Wrench Co, Grants Pass, OR). The Weed Wrench allowed juvenile sagebrush plants to be extracted from the ground with minimal damage to root systems. Harvested plants were wrapped in wet burlap sacks and placed in a cooler to avoid desiccation and planted within $6 \mathrm{~h}$ of harvest. Transplant size was characterized prior to planting by measuring above- and belowground growth for 10 randomly selected nursery and wildling plants in each year of the study. Ten sagebrush transplants were planted in random locations within each plot in April 2009 or 2010. We used a tree planting bar (JIM-GEM KBC Bar) to make an approximately $20-\mathrm{cm}-$ deep hole, placed the transplant in the hole, and compressed the soil around the plant. Glyphosate herbicide (Roundup, Monsanto Company, St Louis, MO) was applied $\left(4.8 \mathrm{~L} \cdot \mathrm{ha}^{-1}\right)$ to herbicide plots in mid-May of the year of planting using a backpack sprayer with handheld boom; sagebrush transplants were temporarily covered with plastic containers to prevent glyphosate contact during spraying. Our herbicide application procedures would not be logistically practical in field restorations and were used solely to evaluate the influence of reduced competition on transplant establishment.

\section{Data Collection}

Weather data from 2009-2011 were compiled from the Elko Airport (for the native and cheatgrass sites) and South Fork State Park (for the crested wheatgrass site) weather stations. Species composition of existing vegetation at each site was estimated in July 2010. A 50-m transect was run through the center axis of each site, and we made ocular estimates of herbaceous plant canopy cover and ground cover of litter and bare ground and counted density of all herbaceous plant species within $40 \times 50 \mathrm{~cm}$ quadrats placed at $2-\mathrm{m}$ intervals along the transect. We used this same transect to estimate cover of existing shrubs by species using the line intercept technique 
(Canfield 1941) and a 15-cm gap (Boyd et al. 2007). Shrub density was counted within a 2-m-wide buffer of the 50-m transect. Percent control of herbaceous vegetation was estimated (visually) by plot in July of the year of glyphosate application. Density of live (based on presence of green leaves) transplanted shrubs was estimated by direct count in July or August of 1) the year of planting (2009 and 2010 plantings), 2) the year following planting (2010 planting only), and 3) $2 \mathrm{yr}$ following planting (2009 planting only). Volume of surviving shrubs was used as an index to production and was measured in July 2011. For each shrub, we measured shrub height, maximum canopy diameter, and the length of the diameter perpendicular to maximum. Volume was calculated by multiplying elliptical crown area by height.

\section{Data Analysis}

Data were examined for skewness and kurtosis (PROC UNIVARIATE; SAS Institute 1999). When normality or homogeneity of variance assumptions were violated, data were weighted by the inverse of the treatment variance for analysis (Neter et al. 1990; James and Drenovsky 2007). Abundance data for existing plant species were collated within groups including cheatgrass, forbs, large perennial grasses (all perennial bunchgrasses excluding $\mathrm{Poa}$ ), Sandberg's bluegrass ( $\mathrm{Po} a$ secunda J. Presl), and shrubs. Because of differing data collection intervals based on year of planting, density of planted sagebrush was analyzed within year of planting. Site effects on planted sagebrush density were determined using mixed-model ANOVA (PROC MIXED; Littell et al. 1996) with repeated years $(n=2)$. Because of site differences, further analysis of density data was conducted within site. The effects of herbicide treatment and transplant stock on survival were evaluated using mixed-model ANOVA (PROC MIXED; Littell et al. 1996) with repeated years $(n=2)$. Block and the block $\times$ treatment interaction were considered random effects in the model. Within year of planting, shrub volume data were analyzed by site using mixed-model ANOVA. Volume data for the 2009 planting were analyzed for herbicide treatment and planting stock effects using mixed-model ANOVA, but volume for the 2010 planting was analyzed only by site due to low sample size. Covariance structure for all models was determined using the Akaike information criterion (Littell et al. 1996). When significant $(\alpha=0.05)$ main or interactive effects were detected, we used the LSMEANS procedure (SAS Institute 1999) to determine treatment, year, or site differences $(\alpha=0.05)$. All means are reported with their associated standard errors.

\section{RESULTS}

\section{Weather and Species Composition}

Precipitation during the crop year (October-June) was $127 \%$, $84 \%$, and $132 \%$ of the long-term (50-yr) mean for 2009, 2010, and 2011, respectively, for the native and cheatgrass sites (Elko Airport Weather Station Database) and 119\%, 82\%, and $119 \%$ of the long-term (19-yr) mean for the same years, respectively, at the crested wheatgrass site (South Fork State Park Weather Station Database). Cover of shrubs existing prior to study implementation was less than $5 \%$ at all sites (Table 1). Perennial grass cover was highest $(27.1 \% \pm 3.6)$ at the crested wheatgrass site, but the plant community at this site was monotypic; crested wheatgrass was the only perennial grass encountered, and cheatgrass and forbs were absent (Table 1). Forb cover was highest at the native site $(19.2 \% \pm 2.7)$, and bare ground at the cheatgrass site $(29.5 \% \pm 4.6)$ was about half that of remaining sites (Table 1).

\section{Percent Herbicide Kill and Transplant Size}

Percent kill of glyphosate-sprayed herbaceous plants in 2009 was $98.4 \pm 0.67 \%, 73.9 \pm 8.20 \%$, and $96.4 \pm 0.28 \%$ and in 2010 was $95.3 \pm 1.71 \%, 91.0 \pm 2.84 \%$, and $65 \pm 5.21 \%$ for the cheatgrass, native, and crested wheatgrass sites, respectively. Aboveground growth (i.e., height) of nursery stock plants at the time of planting averaged $12.7 \pm 1.05 \mathrm{~cm}$ in 2009 and $7.1 \pm 0.78 \mathrm{~cm}$ in 2010; aboveground growth for wildlings was $11.7 \pm 0.95 \mathrm{~cm}$ in 2009 and $18.06 \pm 1.29 \mathrm{~cm}$ in 2010 . Belowground growth for nursery stock was $10.3 \pm 0.42 \mathrm{~cm}$ in 2009 and $13.5 \pm 1.84 \mathrm{~cm}$ in 2010, while wildling belowground growth was $18.02 \pm 1.46 \mathrm{~cm}$ in 2009 and $18.1 \pm 1.67 \mathrm{~cm}$ in 2010.

\section{Site Effects}

For sagebrush planted in 2009, density of surviving sagebrush transplants varied by site $(P=0.002)$ and was about $75 \%$ higher for the native as compared to the cheatgrass and crested wheatgrass sites (Fig. 1a). For the 2010 planting, surviving density varied by site $(P=0.033)$ and was 2.5 - and 3 -fold higher for the cheatgrass and native sites, respectively, as compared to the crested wheatgrass site (Fig. 1b). Shrub volume varied by site for the $2010(P=0.037)$ but not the 2009 planting $(P=0.167)$. Volume was over 17 times higher at the native site as compared to the crested wheatgrass site for the 2010 planting (Fig. 1c)

\section{Planting}

Surviving density of planted sagebrush at the cheatgrass site varied by the interaction of year and transplant stock $(P=0.028$; Fig. 2a). Surviving density of nursery stock was almost 3-fold higher than sagebrush wildlings in 2009 and 2011. Nursery stock density decreased from $4.4 \pm 0.96$ (plants $\cdot 10 \mathrm{~m}^{-2}$ ) in the year of planting (2009) to $1.6 \pm 0.76$ (plants.10 $\mathrm{m}^{-2}$ ) in 2011. Density of surviving sagebrush transplants at the native site varied by the interaction of year, stock, and herbicide treatment $(P=0.008$; Fig. $2 b)$. Density was highest for nursery stock in plots sprayed with glyphosate in $2009\left(7.0 \pm 0.71\right.$ plants $\left.\cdot 10 \mathrm{~m}^{-2}\right)$ and lowest for nonsprayed wildling plots in $2011\left(0.0 \pm 0.0\right.$ plants $\cdot 10 \mathrm{~m}^{-2}$; Fig. 2b). On the crested wheatgrass site, density of surviving sagebrush transplants was highest $(P=0.018)$ in glyphosate plots $\left(2.6 \pm 0.50\right.$ plants. $10 \mathrm{~m}^{-2}$; Fig. $\left.2 \mathrm{c}\right)$ and varied by the interaction of year and stock $(P=0.009$; Fig. $2 \mathrm{~d})$. Surviving density was 5 - and approximately 3 -fold less for wildling stock in 2009 and 2011, respectively. Average shrub volume varied by herbicide treatment $(P=0.054)$ but not plant stock $(P=0.873)$ for the 2009 planting and was nearly 4 -fold higher for plots treated with glyphosate (Fig. 2e). 
Table 1. Ground and vegetation functional group cover for sites used to transplant Wyoming big sagebrush seedlings and wildlings. Data were collected in July 2010. Values within a site and cover category are based on 25 quadrats spaced at 2-m intervals along a 50-m transect. ${ }^{1}$

\begin{tabular}{|c|c|c|c|c|c|c|c|c|c|c|c|c|c|c|c|c|}
\hline \multirow[b]{3}{*}{ Site } & \multicolumn{16}{|c|}{ Canopy cover (\%) } \\
\hline & \multicolumn{2}{|c|}{ Bare ground } & \multicolumn{2}{|c|}{ Litter } & \multicolumn{2}{|c|}{ Rock } & \multicolumn{2}{|c|}{ Cheatgrass } & \multicolumn{2}{|c|}{ Forb } & \multicolumn{2}{|c|}{ Perennial grass } & \multicolumn{2}{|c|}{ Sandberg bluegrass } & \multicolumn{2}{|c|}{ Shrub } \\
\hline & $\bar{x}$ & SE & $\bar{x}$ & SE & $\bar{x}$ & SE & $\bar{x}$ & SE & $\bar{x}$ & SE & $\bar{x}$ & SE & $\bar{x}$ & SE & $\bar{x}$ & SE \\
\hline Native & 63.0 & 2.5 & 18.2 & 2.2 & 2.7 & 0.4 & 18.4 & 3.4 & 19.2 & 2.7 & 17.8 & 4.2 & 4.4 & 1.2 & 1.4 & NA \\
\hline Cheatgrass & 29.5 & 4.6 & 58.8 & 4.1 & 0.1 & 0.1 & 41.3 & 3.8 & 7.4 & 1.1 & 1.4 & 1.2 & 0.0 & 0.0 & 4.7 & NA \\
\hline Crested wheatgrass & 64.0 & 3.9 & 21.5 & 2.8 & 0.0 & 0.0 & 0.0 & 0.0 & 0.0 & 0.0 & 27.1 & 3.6 & 0.0 & 0.0 & 0.1 & NA \\
\hline
\end{tabular}

${ }^{1} \mathrm{NA}=$ not applicable.

\section{Planting}

Density of surviving sagebrush transplants at the cheatgrass site varied with the plant stock $\times$ herbicide treatment $(P=0.007)$ and year $\times$ herbicide treatment $(P=0.020)$ interactions (Figs. 3a and $3 \mathrm{~b}$ ). Values ranged from $2.6 \pm 0.48$ (plants $10 \mathrm{~m}^{-2}$ ) in 2010 glyphosate plots to $0.3 \pm 0.15$ (plants $\cdot 10 \mathrm{~m}^{-2}$ ) in 2011 nonsprayed plots. Where glyphosate was applied, sagebrush density was 2.5- and 3-fold higher for 2010 and 2011, respectively. Glyphosate increased the density of nursery stock sagebrush by $80 \%$ and increased density of wildling sagebrush by over $300 \%$. Density of surviving sagebrush transplants at the native site varied by year $(P<0.001)$ and herbicide treatment $(P=0.014$; Figs. $3 \mathrm{c}$ and $3 \mathrm{~d})$. Density was 2-fold higher in 2010 and increased approximately 400\% with application of glyphosate. Similarly, density of surviving sagebrush transplants on the crested wheatgrass site varied by year $(P=0.004)$ and herbicide treatment $(P=0.057$; Figs. 3e and 3f), was highest in 2010, and increased approximately 3fold with herbicide treatment.

\section{DISCUSSION}

The need for effective Wyoming big sagebrush restoration techniques has increased dramatically with the continued expansion of annual grasses and increased frequency of wildfires. In association with annual grass proliferation, the average size of wildfires has increased markedly in recent years (Keane et al. 2008). Within large wildfires, residual unburned shrub islands serve as critical seed sources for natural recovery (Longland and Bateman 2002). However, such sources may not be adequate to supply interior portions of burned areas (Ziegenhagen and Miller 2009), and existing sagebrush soil seed pools generally lose viability within $2 \mathrm{yr}$ following fire (Wijayratne and Pyke 2009). Under these conditions, active restoration is often necessary to maintain sagebrush populations. Our data suggest that transplanting seedlings or juvenile plants is a viable method for re-establishing Wyoming big sagebrush on depleted sites. Overall, $96 \%$ of the 24 combinations of planting year, site, plant stock, and herbicide treatment had live plants 1-2 yr postplanting. Other authors have reported successful establishment of transplants with a variety of shrub taxa, including Atriplex, Cowania, Archtostaphylow, and Symphoricarpos (Evans and Young 1977; Van Epps and McKell 1983; Petersen et al. 2004). The success of the current study is in sharp contrast to previous reports suggesting low success rates of drilling or broadcasting sagebrush as seed. For example, Lysne and Pellant (2004) reported failure in 23 of 35 aerial seedings of big sagebrush in the Great Basin.

As predicted, glyphosate generally increased survival of both wildling and nursery stock across sites and years (Figs. 2 and 3). Glyphosate treatment was particularly effective on the native site for the 2009 planting, where density of transplants in this treatment did not differ between the year of planting and $2 \mathrm{yr}$ subsequent for either nursery or wildling stock (Fig. 2b). Dramatically increased shrub volume for plots planted in 2009 and treated with glyphosate suggests substantially increased production of sagebrush transplants with reduced herbaceous competition (Fig. 2e). Improved seedling establishment and vigor with diminished herbaceous competition is consistent with previous work indicating more rapid recovery, growth, or establishment of sagebrush under conditions of reduced competition from herbaceous vegetation in general and perennial grasses in particular (Austin et al. 1994; Austin and Urness 1995; Schuman et al. 1998; Boyd and Svejcar 2011).

The use of herbicides to foster sagebrush re-establishment may be of particular interest in management of crested wheatgrass plant communities. Multiple published accounts suggest that reintroduction of native perennial herbaceous and woody species to crested wheatgrass communities is extremely difficult, even following mechanical or chemical control of crested wheatgrass, due to the competitive nature of this species (Hulet et al. 2010; Fansler and Mangold 2011). Crested wheatgrass competes strongly with Wyoming big sagebrush at the seedling stage, but once established, sagebrush has high persistence in crested wheatgrass communities due to niche differentiation between these species (Gunnell et al. 2010). Our data indicate that sagebrush transplants, particularly when planted with chemical control of crested wheatgrass, can help to diversify these plant communities. Sagebrush would not only increase species richness in crested wheatgrass communities but also increase diversity of habitat structure important to a variety of wildlife species (McAdoo et al. 1989; Kennedy et al. 2009). These same benefits may also be important in monotypic stands of annual grasses, where establishment of native perennials from seed has proven difficult (Davies et al. 2011).

A complicating variable at our crested wheatgrass site was the impact of black-tailed jackrabbits (Lepus californicus). Although no objective abundance indices were calculated, jackrabbit droppings were abundant at this site. We also made multiple sightings of jackrabbits during each crested wheatgrass site visit and documented widespread "waste cutting" of crested wheatgrass, especially during 2009. Responsibility for waste cutting was readily verified by fresh jackrabbit droppings 


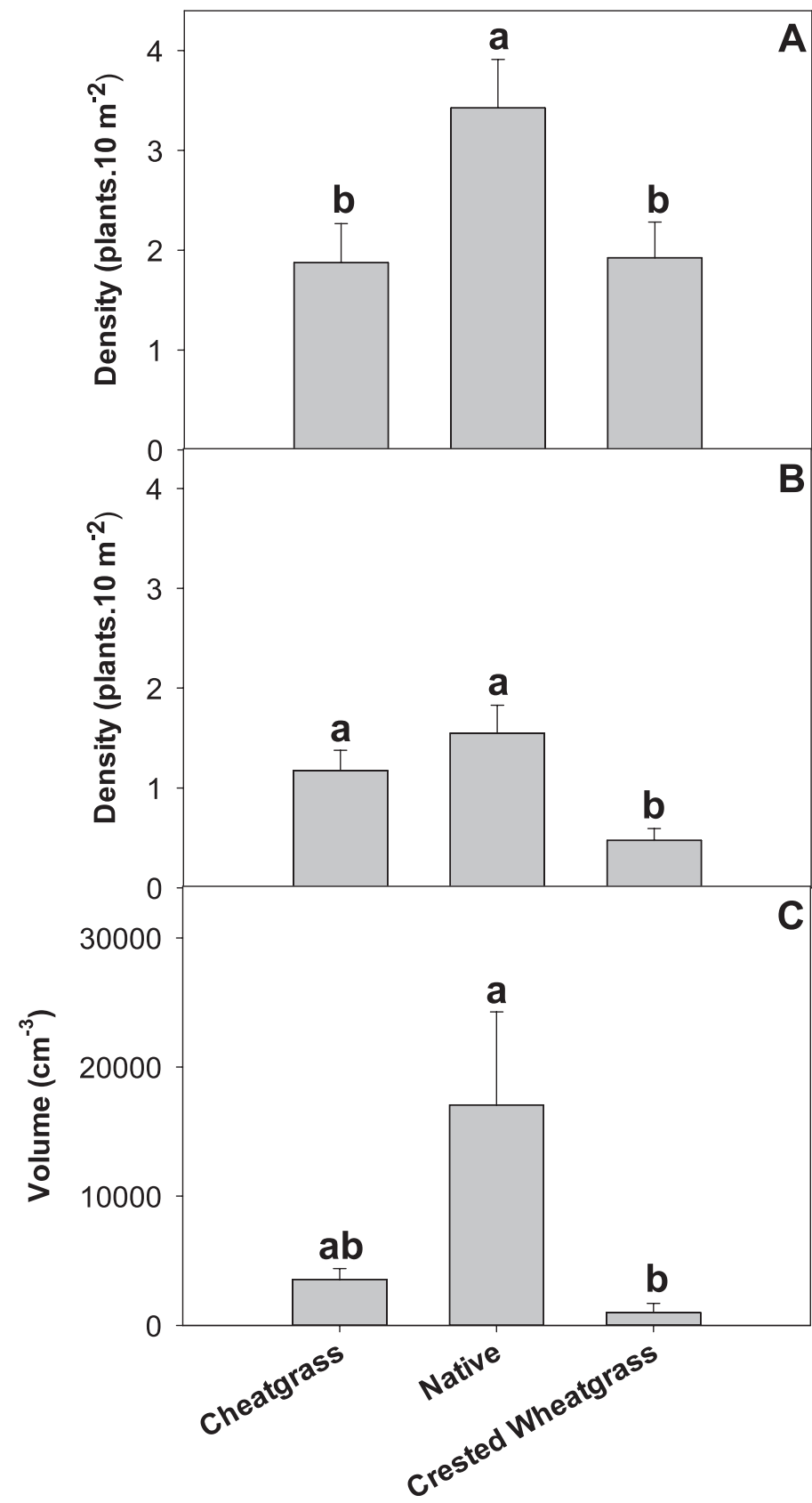

Figure 1. Surviving density or volume $(n=40)$ for transplanted sagebrush as a function of site for plots planted in the spring of 2009 (A) or 2010 (B, C) in Wyoming big sagebrush plant communities in northern Nevada. Data are the average of values for the end of the first growing season following planting (2009) and the second year postplanting (2011) (A) and the end of the first growing season (2010) and the first year postplanting (2011) (B, C). Bars represent mean values and associated standard errors. Within a graph, bars without a common letter are different at $\alpha=0.05$.

in harvested areas; livestock access to the crested wheatgrass site was prevented by fencing. (Note that livestock had access to the remaining two sites, but herbaceous utilization was light, and there was no damage to or consumption of sagebrush transplants by livestock.) Comparatively, only scant jackrabbit sign was observed at the other two sites, and no animals were directly observed. The forage preference affinity of black-tailed jackrabbits for crested wheatgrass is well documented (McA- doo et al. 1987; Ganskopp et al. 1993), explaining their disproportionate attraction to our crested wheatgrass study site.

During sagebrush survival counts at the crested wheatgrass site in 2009 and 2010, we counted 28 and 27 first-year sagebrush transplants, respectively, that were cut just above ground level, apparently by black-tailed jackrabbits (based on accompanying fresh pellet sign in the study plot vicinity). Black-tailed jackrabbits are known to eat shrubs, including sagebrush, and have an affinity for young succulent vegetation (Fagerstone et al. 1980). Since Wyoming big sagebrush does not sprout, the seedlings cut near ground level were direct mortalities caused by the black-tailed jackrabbits. We also noted that several other planted seedlings were completely missing from plots at the crested wheatgrass site (six in 2009 and eight in 2010), possibly pulled up by the roots during the process of jackrabbit depredation. Comparatively, during the same data collection episodes, we observed a total of seven sagebrush seedlings harvested by jackrabbits at the other sites: none in 2009 and seven in 2010, including six at the cheatgrass site and 1 at the native site.

We found that density of surviving nursery transplants was higher on most sites with the 2009 but not the 2010 planting. Relative performance of plant stock between years may be related to plant size in that aboveground growth of nursery stock in the 2010 planting was less developed than in 2009, whereas wildling stock had more extensive aboveground growth in 2010 than 2009. Soil moisture conditions at time of wildling harvest could also affect subsequent postplanting survival. Our field observations indicate that harvesting wildlings under conditions of dry soils will lead to excessive root tearing as the plants are extracted from the soil. The specific water content needed to prevent root tear will vary according to soil texture and profile. In general, we found that wildling harvest was most feasible during spring as opposed to fall due to more favorable soil water conditions.

Surviving density of transplants in our study, at 1-2 yr postplanting, was generally half or less than half of that reported for intact Wyoming big sagebrush plant communities in our region. For example, Davies and Bates (2010) found sagebrush densities of 5 plants $10 \mathrm{~m}^{-2}$ in nondisturbed Wyoming big sagebrush plant communities in southeastern Oregon. However, at longer time intervals, transplant success rates in the present study may be sufficient to impact successional trajectories by establishing seed source islands (Reever Morghan and Sheley 2005) capable of supplying sagebrush propagules to a larger area (Shaw et al. 2005). The concept of island seeding may be particularly important for spatially limited restoration efforts (e.g., Paschke et al. 2000; Petersen et al. 2004) or for targeting critical sites within largerscale projects. Alternatively, planting transplants at double the density used in the current study (i.e., 20 plants $\cdot 10 \mathrm{~m}^{-2}$ vs. 10 plants $10 \mathrm{~m}^{-2}$ ) would theoretically result in a sagebrush density reflective of site capacity, assuming survival rates similar to those found in this study.

Because the focus of this study was on small plots, we did not include a rigorous economic comparison of the techniques we tested versus those used at larger scales (e.g., drill or broadcast seeding). That said, the major costs of transplant techniques are 

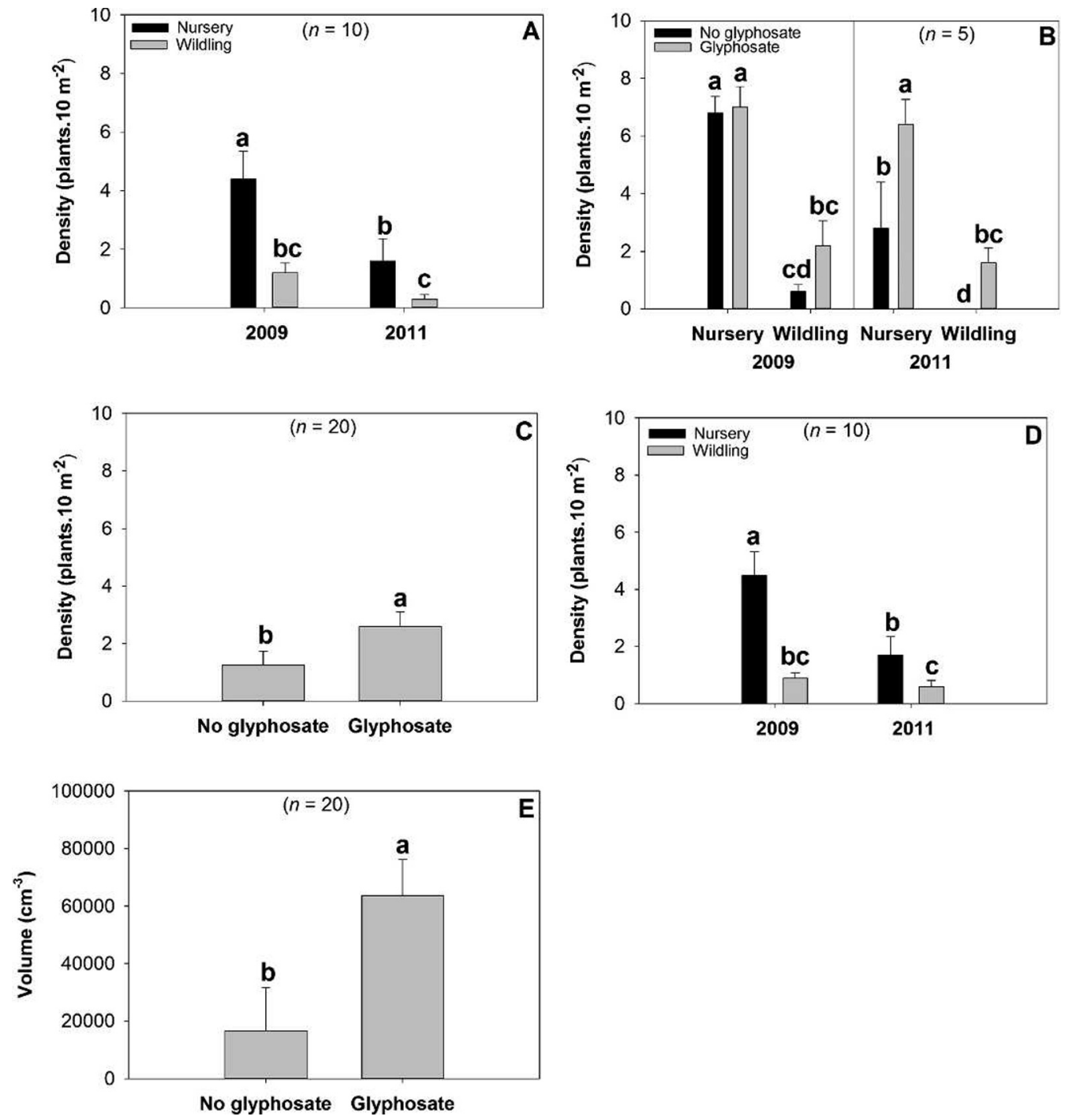

Figure 2. Surviving density or volume of transplanted sagebrush as a function of plant stock (nursery or wildling), glyphosate application, and year for plots planted in the spring of 2009 in Wyoming big sagebrush plant communities in northern Nevada. Data were collected at the end of the first growing season following planting (2009) and during the second year postplanting (2011). Graphs depict density for a cheatgrass-dominated site (A), a nativedominated site (B) and a crested wheatgrass-dominated site (C, D), and volume as a function of herbicide treatment (E). Bars represent mean values and associated standard errors. Within a graph, bars without a common letter are different at $\alpha=0.05$.

related to purchasing plant materials (i.e., for nursery stock), personnel expenses for planting, and plant harvest (i.e., for wildlings). Our nursery stock plants were valued at $\$ 1.50$ each, and planting (with either nursery or wildling stock) took about $30 \mathrm{~s}^{-1} \cdot$ plant. Harvest rate for wildlings was approximately 3 plants $\cdot \min ^{-1} \cdot$ person $^{-1}$. For field restoration efforts, these costs could be substantial, particularly for large-scale projects. However, the effectiveness of the transplant technique could work to offset expenses relative to less reliable seeding methods (e.g., broadcast seeding) given that the cost of successful restoration, on a unit area basis, is the cost of applying restorative practices divided by the success rate (Boyd and Davies 2012b). Additionally, economic factors may be less important for smaller-scale restoration activities, such as improving key wintering habitat for sage-grouse or mule deer (Odocoileus hemionus).

\section{MANAGEMENT IMPLICATIONS}

We found that successful transplanting (either wildlings or nursery stock) of Wyoming big sagebrush can be achieved on a variety of ecological sites where sagebrush has been depleted, particularly when combined with glyphosate to control competing vegetation. From a logistical standpoint, use of transplants will be most applicable to restoration projects of limited spatial scale, such as establishing sagebrush islands that could theoretically supply a seed source for gradual re-establishment of sagebrush within larger areas (e.g., postfire rehabilitation). However, greater restoration success of transplants as compared to direct seeding methods increases the utility of transplants, particularly on low- to mid-elevation moisture-limited sites where direct seeding methods have low success rates. The current study design is 

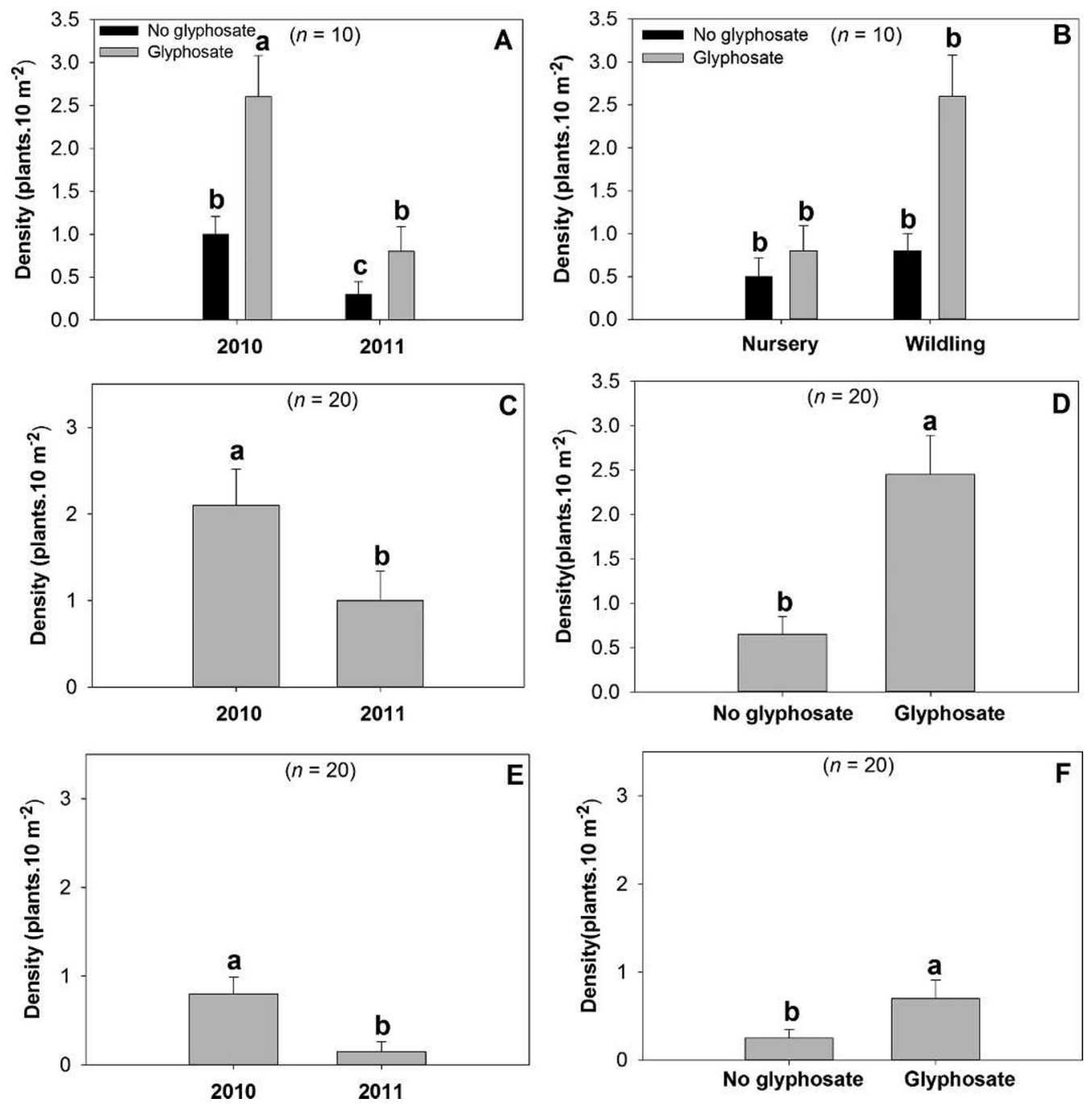

Figure 3. Surviving density for transplanted sagebrush as a function of plant stock (nursery or wildling), glyphosate application, and year for plots planted in the spring of 2010 in Wyoming big sagebrush plant communities in northern Nevada. Data were collected at the end of the first postplanting growing season (2010) and the subsequent year (2011). Graphs depict results for a cheatgrass-dominated site (A, B), a native-dominated site (C, D), and a crested wheatgrass-dominated site (E, F). Bars represent mean values and associated standard errors. Within a graph, bars without a common letter are different at $\alpha=0.05$.

limited in that a lack of replication within site type prevents conclusions regarding the role of vegetation composition on establishment of sagebrush transplants. That said, our findings cause us to hypothesize that maintaining relatively intact herbaceous plant communities may be important to sagebrush establishment, given that plantings were most successful on the "native" site as compared to cheatgrass or crested wheatgrass sites.

\section{ACKNOWLEDGEMENTS}

The authors wish to thank John Swanson, Brett Bingham, and Clare Poulsen for their help in the field aspects of this study, and Steve Monsen for his invaluable advice regarding shrub transplanting. We also appreciate helpful reviews of an earlier draft of this manuscript from Kirk Davies and Dustin Johnson.

\section{LITERATURE CITED}

Aldridge, C. L., S. E. Nielsen, H. L. Beyer, M. S. Boyce, J. W. Connelly, S. T. Knick, and M. A. SCHROEDER. 2008. Range-wide patterns of greater sage-grouse persistence. Diversity and Distributions 14:983-994.

Austin, D. D., And P. J. UnNess. 1995. Effects of horse grazing in spring on survival, recruitment, and winter injury damage of shrubs. Great Basin Naturalist 55:267270.

Austin, D. D., P. J. Urness, and S. L. Durham. 1994. Impacts of mule deer and horse grazing on transplanted shrubs for revegetation. Journal of Range Management 47:8-11.

Boyd, C. S., J. D. Bates, and R. F. Miller. 2007. The influence of gap size on sagebrush cover estimates with the use of line intercept technique. Rangeland Ecology \& Management 60:199-202.

Boyd, C. S., and K. W. Davies. 2010. Shrub microsite influences perennial grass establishment. Rangeland Ecology \& Management 63:248-252.

Boyd, C. S., AND K. W. Davies. 2012a. Differential seedling performance and environmental correlates in shrub vs. interspace environments. Journal of Arid Environments 87:50-57. 
Boyd, C. S., And K. W. Davies. 2012b. Spatial variability in cost and success of revegetation in a Wyoming big sagebrush Community. Environmental Management 50:441-450.

Boyd, C. S., AND T. J. SveJcAR. 2011. The influence of plant removal on succession in Wyoming big sagebrush. Journal of Arid Environments 75:734-741.

Brooks, M. L., C. M. D’Antonio, D. M. Richardson, J. B. Keeley, J. M. DiTomaso, R. J. Hobbs, M. Pellant, and D. Pyke. 2004. Effects of invasive alien plants on fire regimes. BioScience 54:677-688.

Canfield, R. 1941. Application of line interception in sampling range vegetation. Journal of Forestry 39:388-394.

Chambers, J. C. 2000. Seed movements and seedling fates in disturbed sagebrush steppe ecosystems: implications for restoration. Ecological Applications 10:1400-1413.

Comer, P., J. Kagan, M. Heiner, and C. Tobalske. 2002. Sagebrush vegetation in the western United States. Map 1:200,000 scale. Boise, ID, USA: USGS Forest and Rangeland Ecosystems Science Center; Boulder, CO, USA: The Nature Conservancy.

Crawford, J. A., R. A. Olson, N. E. West, J. C. Mosley, M. A. Schroeder, T. D. Whitson, R. F. Mlller, M. A. GregG, and C. S. Boyd. 2004. Ecology and management of sage-grouse and sage-grouse habitat. Journal of Range Management 57:2-19.

Davies, K. W., AND J. D. Bates. 2010. Vegetation characteristics of mountain and Wyoming big sagebrush plant communities in the northern Great Basin. Rangeland Ecology \& Management 57:203-210.

Davies, K. W., J. D. Bates, AND J. J. James. 2009. Microsite and herbaceous vegetation heterogeneity after burning Artemisia tridentata steppe. Oecologia 159:98-110.

Davies, K. W., J. D. Bates, and R. F. Mılıer. 2007. The influence of Artemisia tridentata spp. wyomingensis on microsite and herbaceous vegetation heterogeneity. Journal of Arid Environments 69:441-457.

Davies, K. W., C. S. Boyd, J. L. Beck, J. D. Bates, T. J. Svejcar, and M. A. Gregg. 2011. Saving the sagebrush sea: an ecosystem conservation plan for big sagebrush plant communities. Biological Conservation 144:2573-2584.

Evans, R. A., And J. A. Young. 1977. Weed control-revegetation systems for big sagebrush-downy brome rangeland. Journal of Range Management 30:331336.

Fagerstone, K. A., G. K. Lavole, and R. E. Griffith, JR. 1980. Black-tailed jackrabbit diet and density on rangeland and near agricultural crops. Journal of Range Management 33:239-233.

Fansler, V. A., and J. M. Mangold. 2011. Restoring native plants to crested wheatgrass stands. Restoration Ecology 19:16-23.

Ganskopp, D., B. Myers, AND S. Lambert. 1993. Black-tailed jackrabbit preferences for eight forages used for reclamation of Great Basin rangelands. Northwest Science 67:246-250.

Ganskopp, D., T. Svejcar, F. Taylor, and J. Farstvedt. 2004. Can spring cattle grazing among young bitterbrush stimulate shrub growth? Journal of Range Management 57:161-168.

GunnelL, K. L., T. A. Monaco, C. A. Call, and C. V. Ransom. 2010. Seedling interference and niche differentiation between crested wheatgrass and contrasting native Great Basin species. Rangeland Ecology \& Management 63:443-449.

Hulet, A., B. A. Roundy, and B. Jessop. 2010. Crested wheatgrass control and native plant establishment in Utah. Rangeland Ecology \& Management 63:450-460.

Jackson, R. B., and M. M. Caldwell. 1993a. Geostatistical patterns of soil heterogeneity around individual perennial plants. Journal of Ecology 81:683-692.

JaCKSON, R. B., AND M. M. CALDWELL. 1993b. The scale of nutrient heterogeneity around individual plants and its quantification with geostatistics. Ecology 74:612-614.

James, J. J., AND R. E. Drenovsky. 2007. A basis for relative growth rate differences between native and invasive forb seedlings. Rangeland Ecology \& Management 60:395-400

Keane, R. E., J. K. Agee, P. Fule, J. E. Keeley, C. Key, S. G. Kitchen, R. Miller, and L. A. SCHULTE. 2008. Ecological effects of large fires on the US landscapes: benefit or catastrophe? International Journal of Wildland Fire 17:696-715.
Kennedy, P. L., S. J. DeBano, A. M. Bartuszevige, and A. S. Lueders. 2009. Effects of native and non-native grassland plant communities on breeding passerine birds: Implications for restoration of northwest bunchgrass prairie. Restoration Ecology 17:515-525.

Littell, R. C., G. A. Milliken, W. W. Stroup, and R. D. Wolfinger. 1996. SAS system for mixed models. Cary, NC, USA: SAS Institute.

Longland, W. S., And S. L. Bateman. 2002. Viewpoint: the ecological value of shrub islands on disturbed sagebrush rangelands. Journal of Range Management 55:571575.

Lysne, C. R., and M. Pellant. 2004. Establishment of aerially seeded big sagebrush following southern Idaho wildfires. Boise, ID, USA: Department of the Interior, Bureau of Land Management. Technical Bulletin 2004-01. 14 p.

McAdoo, J. K., W. S. Longland, G. J. Cluff, and D. A. Klebenow. 1987. Use of new rangeland seedings by black-tailed jackrabbits. Journal of Range Management 40:520-524.

McAdoo, J.K., W. S. Longland, and R. A. Evans. 1989. Nongame bird community responses to sagebrush invasion of crested wheatgrass seedings. Journal of Wildlife Management 53:494-502.

McArthur, S. D., and R. Stevens. 2004. Composite shrubs. In: S. B. Monsen, S. Stevens, and N. Shaw [comps.]. Restoring western ranges and wildlands. Fort Collins, CO, USA: USDA Forest Service Rocky Mountain Research Station. General Technical Report RMRS-GTR-136-vol-2. p. 493-537.

Neter, J., W. Wasserman, and M. H. Kutner. 1990. Applied linear statistical models: regression, analysis of variance and experimental design. 3rd ed. Homewood, IL, USA: Irwin. $1408 \mathrm{p}$.

Paschke, M. W., C. Deleo, and E. F. Redente. 2000. Revegetation of roadcut slopes in Mesa Verde National Park, U.S.A. Restoration Ecology 8:276-282.

Perryman, B. L., A. M. Maier, A. L. Hild, and R. A. Olson. 2001. Demographic characteristics of big sagebrush in Wyoming. Journal of Range Management $54: 166-170$

Petersen, S. L., B. A. Roundy, and R. M. Bryant. 2004. Revegetation methods for highelevation roadsides at Bryce Canyon National Park, Utah. Restoration Ecology 12:248-257.

Reever Morghan, K. J., and R. L. Sheley. 2005. Seed island may promote establishment and expansion of native species in reclaimed mine sites (Montana). Ecological Restoration 23:214-215.

SAS InStitute. 1999 SAS procedures guide, release 8.0. Cary, NC, USA: SAS Institute.

Schuman, G. E., D. T. Booth, AND J. R. Cockrell. 1998. Cultural methods for establishing Wyoming big sagebrush on mined lands. Journal of Range Management 51:223-230.

Shaw, N. L., A. M. DeBolt, and R. Rosentreter. 2005. Reseeding big sagebrush: techniques and issues. In: N. Shaw, M. Pellant, and S. B. Monsen [comPS.]. Sagegrouse habitat restoration symposium proceedings; 4-7 June 2001; Boise, ID, USA. Fort Collins, C0, USA: USDA Forest Service Rocky Mountain Research Station. Proc. RMRS-P-38. p. 99-108.

Shipley, L. A., T. B. DaVILA, N. J. Thines, And B. A. ElaAs. 2006. Nutritional requirements and diet choices of the pygmy rabbit (Brachylagus idahoensis): a sagebrush specialist. Journal of Chemical Ecology 32:2455-2474.

Van Epps, G. A., And C. M. McKell. 1983. Effect of weedy annuals on the survival and growth of transplants under arid conditions. Journal of Range Management 36:366-369.

WEST, N. E. 1983. Western Intermountain sagebrush steppe, In: N. E. West [ED.]. Temperate deserts and semideserts, vol. 5: ecosystems of the world. Amsterdam, the Netherlands: Elsevier. p. 351-374.

Wijayratne, U. C., and D. A. PYKe. 2009. Investigating seed longevity of big sagebrush (Artemisia tridentata). Reston, VA, USA: US Geological Survey. Open-File Report 2009-1146. 26 p.

Ziegenhagen, L. L., and R. F. Miller. 2009. Postfire recovery of two shrubs in the interiors of large burns in the Intermountain West, USA. Western North American Naturalist 69:195-205. 